use of terminology which must be confusing to the beginning student. For example, "individual ownership" (p. 17), "individual enterprise" (p. 18), "proprietorship" (pp. 18-20), and "individual enterprise" again (pp. 32-33) - all applied to the same concept. In Chapter IV there are several references to "common stock"; in Chapter V "ordinary stock" is used (except for "common stock" three times on one page); in Chapter VI the usage goes back to "common stock."

Professor Hicks has introduced several worth-while teaching aids, not found in the first edition. There are, at the end of each chapter, a list of questions, several projects in the subject matter of the chapter, and a bibliography. In a full-year course, the suggested projects should be especially useful; they are well formulated and are within the scope of source material available in college libraries. Another innovation, claimed to be "for the first time in the history of the field," is photographic illustrations from the worlds of industry and finance.

For an advanced, full-year course, there is plenty of material in this text. I doubt whether it is as suitable for an introductory course, particularly if only one semester in length.

\section{Haverford College}

Howard M. Teaf, JR.

Lintner, John. Mutual Savings Banks in the Savings and Mortgage Markets. Pp. xi, 559. Boston: Division of Research, Graduate School of Business Administration, Harvard University, 1948. $\$ 5.50$.

Mutual savings banks have a long and honorable history of service to the communities in which they exist. Professor Lintner thoroughly investigates their changing position as depositories and investors of the people's savings in the seventeen states in which they operate, and particularly in Massachusetts where their importance is very great. Nevertheless, the relevance of this study is not limited to one state, because the Massachusetts experience can probably be extended to the other sixteen states, and because the holdings of the mutual savings banks are diversified.
Mutual savings banks have been losing ground to other thrift institutions which have emerged in later years. The public apparently prefers to save its money in other forms, such as life insurance policies.

On the whole, mutual savings banks have made comparatively little effort to induce the public to save systematically with them. In Massachusetts, however, they have provided life insurance. They have tried to encourage systematic saving through Christmas clubs, school savings programs, and so forth. The provision of life insurance has been successful in every respect. But the other mentioned services have not always paid their way, and although the service to the community is beyond question, it is not clear, from the record presented by the author, that they have helped to put the mutual savings banks in a more competitive position vis$\grave{a}$-vis the other thrift institutions.

By far the larger portion of Professor Lintner's book deals with the investment experience of the mutual savings banks. He studies very exhaustively the experience with mortgages, which is appropriate in view of their importance in the portfolio.

Mutual savings banks, though traditional lenders on real estate, became quite reluctant lenders after 1931, an attitude which changed only after the recent hostilities ended and long after other mortgage investors had re-entered the mortgage market. Indeed, "savings banks in every year after 1931 placed their entire increases in resources in government bonds -and in addition placed all the funds released, on balance, from all other investments, in the government portfolio. The government portfolio was increased even in the years in which total resources declined" (p. 224).

This reluctance is understandable. Mutual savings banks sustained big losses on their mortgages during the Great Depression. Yet Lintner finds that mortgages as a whole proved a good investment in the sense that they earned more than longterm government bonds, even after allowance for actual losses. The losses, furthermore, could have been cut by better policies of the banks. Lintner finds that 
unmistakable warning signals as to what was coming appeared already in the early twenties. The general use of amortized mortgages such as are common now, and the early accumulation of adequate valuation reserves, would have reduced losses. Needless to say, no set formula can take the place of the experienced judgment of the banker. Nevertheless, the author makes it quite clear that not everything that happened during the depression was an act of God.

The analysis of the mortgage experience in its details is extremely interesting, but cannot, because of lack of space, be summarized here. Two points may be mentioned. First, experience with conventional mortgages was much better when the properties on which they were given were located near the bank holding the mortgage.

Secondly, residential properties proved a much better risk by any standards than income properties, and one-family residences proved better risks than other residential properties. Many explanations could be given: loans on residential properties are smaller, and the portfolio can thus be diversified. The recovery in residential properties started earlier than that in income properties. Probably also (though this is on the reviewer's and not the author's responsibility), smaller residential properties can be more readily substituted for each other than incomeproducing properties, making both judgment as to their real worth and final disposal much easier.

Altogether, Professor Lintner has presented an enormous and comprehensive mass of valuable material in what appears to this reviewer a definitive form. It is unlikely that this book will be superseded in the foreseeable future.

\section{University of Michigan}

\section{W. F. STOLPER}

Graham, Benjamin. The Intelligent Investor. Pp. xii, 276. New York: Harper \& Brothers, [1949]. $\$ 3.50$.

In an effort to provide laymen with specific and practicable investment programs, Mr. Graham divides lay investors into two broad groups: the "defensive, or the conservative," investor; and the "aggressive, or enterprising," investor. The former emphasizes avoidance of serious losses and is free of effort, annoyance, and the need for making frequent decisions. The latter is willing to devote time and care to the selection of his holdings.

The defensive investor is advised to divide his portfolio between United States Savings Bonds (and/or tax-exempt state and municipal bonds if the investor's tax position warrants) and either a diversified list of leading common stocks or the shares of leading investment funds. $\mathrm{He}$ is cautioned against buying his stocks when prices seem unreasonably high in the light of past market experience. The bond component of the portfolio is 25 to 75 per cent, "depending largely on subjective considerations-the need he [the investor] feels for a somewhat higher income, on the one hand, and for price stability on the other."

In addition to the investments suitable for the defensive investor, the aggressive investor may acquire: growth stocks (but he must beware of paying excessively for them); representative common stocks when the general market is historically low; secondary common stocks, corporate bonds, and preferred stocks, at bargain levels; and undervalued securities involved in "special situations." The aggressive investor will doubtless have a greater turnover in his holdings than the defensive type.

The reasonableness of expression that runs throughout this book and the many ideas (particularly those that relate to the valuing of individual securities) that will prove helpful to the lay investor are most disarming for the critic. The book has many good points, but to this reviewer it has a major defect. Mr. Graham's outline of specific investment programs for broad groups of persons runs counter to what I regard as a basic idea of investment theory and good practice, namely, that each investor has unique problems that require a unique combination of investments to effect a reasonable solution. These problems can never be solved to complete satisfaction; he can never, for example, get both the return and the safety of principal that he would like to 